\title{
PENGGUNAAN MODEL PROJECT BASED LEARNING UNTUK MENINGKATKAN KETRAMPILAN MENULIS TEKS FABEL ATAU LEGENDA
}

\author{
ISA APRIL SETYAWATI \\ MTs Negeri 2 Kota Semarang \\ e-mail: isaapri10404@gmail.com
}

\begin{abstract}
ABSTRAK
Penelitian ini bertujuan untuk meningkatkan ketrampilan menulis teks fabel atau legenda pada peserta didik. Penelitian yang digunakan adalah penelitian tindakan kelas. Yang diteliti adalah penerapan pembelajaran dengan model Project Based Learning, peningkatan keaktifan dan hasil belajar siswa dalam hal menulis teks fabel atau legenda. Penelitian ini menggunakan observasi untuk mengetahui proses pembelajaran Project based Learning, observasi untuk mengetahui keaktifan peserta didik, dan tes untuk mengetahui hasil belajar peserta didik. Hasil penelitian menunjukkan bahwa proses pembelajaran dengan menggunakan model project based learning adalah sebagai berikut : Tahap 1 Apersepsi, Tahap 2: Penentuan proyek dengan menentuan pertanuyaan mendasar, Tahap 3: mendesain perencanaan proyek, Tahap 4: Menyusun Jadwal, Tahap 5: Memonitor peserta didik dan kemajuan proyek, Tahap 6: Menguji Hasil, Tahap 7: Evaluasi pengalaman. Pembelajaran dengan menggunakan model pembelajaran project based learning ini menunjukkan bahwa keaktifan dari kondisi awal ke siklus 1 dan ke siklus 2 persentase peserta didik yang keaktifannya dengan katagori rendah terus menerus mengalami penurunan, yakni 53,13\% -37,50\% -12,50\%. Sedangkan yang katagori sedang terus menerus mengalami peningkatan, yakni $28,12 \%-37,50 \%-56,25 \%$. Adapun yang katagri tinggi pun terus-menerus mengalami kenaikan, yakni 18,75\% - 25,00\% -31,25\%. Penelitian dengan model project based learning ini menunjukkan bahwa hasil belajar siswadari kondisi awal ke siklus 1 , dank e siklus 2 mengalami peningkatan setelah dilakukan tindakan. Persentase peserta didik yang belum tuntas secara terus-menurus mengalami penurunan, yakni 46,63\% -31,25\% $9,37 \%$. Adapun untuk peserta didik yang mengalami ketuntasan hasil belajar terus menerus memgalami peningkatan yakni, 59,37\% -68,75\% - 90,63\%. Nilai rata-rata pun dari kondisi awal ke siklus 1 dan ke siklus 2 pun terus-menerus mengalami peningkatan, yakni 67,19 -72,34 78,94. Indikator keberhasilan PTK ini adalah, bahwa PTK ini dikatakan berhasil jika presentase peserta didik yang nilai hasil belajarnya sudah tuntas mencapai menimal $85 \%$. Dan dari table menunjukkan bahwa persentase peserta didik yang nilainya tuntas sudah mencapai 90,63\%, maka PTK ini sudah berhasil.
\end{abstract}

Kata Kunci: Project besed learning, PTK, Teks Fabel

\section{ABSTRACT}

This study aims to improve the skills of writing fable or legend texts in students. The research used is classroom action research. What is being researched is the application of learning with the Project Based Learning model, increasing student activity and learning outcomes in terms of writing fable or legend texts. This study uses observation to determine the learning process of Project based Learning, observation to determine the activity of students, and tests to determine student learning outcomes. The results showed that the learning process using the project based learning model was as follows: Phase 1 Apperception, Phase 2: Determining the project by determining the basic questions, Phase 3: designing project plans, Phase 4: Preparing a schedule, Phase 5: Monitoring students and project progress, Stage 6: Testing Results, Stage 7: Evaluating the experience. Learning using the project based learning model shows that the activeness from the initial conditions to cycle 1 and to cycle 2 , the percentage of students whose activity is in the low category continues to decrease, namely $53.13 \%-37.50 \%-12.50 \%$. Meanwhile, the medium category continued to increase, namely $28.12 \%-37.50 \%-56.25 \%$. The high category also continued to increase, namely $18.75 \%-25.00 \%-31.25 \%$. This research using a project based learning model shows that student learning outcomes from the initial 


\section{LANGUAGE : Jurnal Inovasi Pendidikan Bahasa dan Sastra Vol 2. No 1. Februari 2022, e-ISSN : 2807-1670 | p-ISSN : 2807-2316}

conditions to cycle 1 and cycle 2 have increased after the action has been taken. The percentage of students who have not completed continuously has decreased, namely $46.63 \%-31.25 \%$ $9.37 \%$. As for students who experience complete learning outcomes continuously, there is an increase, namely, $59.37 \%-68.75 \%-90.63 \%$. The average value from the initial conditions to cycle 1 and to cycle 2 continued to increase, namely $67.19-72.34-78.94$. The indicator of the success of this CAR is that this CAR is said to be successful if the percentage of students whose learning outcomes have been completed reaches a minimum of $85 \%$. And from the table shows that the percentage of students whose grades have completed has reached $90.63 \%$, then this CAR has been successful.

Keywords: Project based learning, CAR, Fable Text

\section{PENDAHULUAN}

Guru bukan hanya sekedar penyampai materi saja, tetapi lebih dari itu guru dapat dikatakan sebagai sentral dan motivator. Gurulah pemegang peranan utama dalam penerapan kurikulum di lapangan. Gurulah yang mengarahkan bagaimana proses belajar mengajar itu dilaksanakan. Karena guru harus dapat membuat pengajaran menjadi lebih efektif dan interaktif dan tentunya juga menarik sehingga bahan pelajaran yang disampaikan akan membuat peserta didik merasa senang dan perlu untuk mempelajari bahan pelajaran.

Dalam proses belajar mengajar di kelas terjadi interaktif antara guru dengan peserta didik, peserta didik dengan peserta didik, dan peserta didk dengan sumber pembelajarannya. Selain itu, dalam proses belajar mengajar agar tercapai hasil yang maksimal dibutuhkan kemampuan guru yang baik dalam mengaktualisasikan kompetensinya secara professional yang meliputi metode, teknik dan strategi belajar mengajar, dan implementasi kurikulum serta evaluasinya. Namun terkadang hasil yang diharapkan masih rendah.

Untuk itu diperlukan suatu upaya dalam rangka meningkatkan mutu pendidikan dan pengajaran, salah satunya adalah dengan memilih strategi atau model pembelajaran dalam menyampaikan materi pelajaran agar diperoleh peningkatan prestasi belajar peserta didik, khususnya pelajaran Bahasa Indonesia di kelas VII yang menggunakan Kurikulum 2013

Dalam kurikulum 2013, mata pelajaran Bahasa Indonesia lebih menekankan pada kemampuan memahami dan menyajikan sebuah teks. Karena butuh konsentrasi dan fokus yang tinggi saat melakukannya. Apalagi jika peserta didik tidak terbiasa membaca dan menyusun / menulis sebuah teks, tentu butuh waktu dalam pemahaman sebuah teks dan menyusunnya. Dan salah satu teks yang harus dipahami peserta didik adalah teks fabel atau legenda. Pemahaman yang dituntut oleh kurikulum berdasarkan Kompetensi Dasarnya yaitu : (3.15) Mengidentifikasi informasi tentang fabel atau legenda daerah setempat yang dibaca dan didengar. (4.15) Menceritakan kembali isi techs fabel atau legenda daerah setempat yang dibaca atau didengar. (3.16) Menelaah struktur dan kebahasaan fabel atau legenda daerah setempat yang dibaca atau didengar. (4.16) Memerankan isi fabel atau legenda daerah setempat yang dibaca dan didengar.

Dan dalam kompetensi dasar inilah peserta didik kelas VII F MTs Negeri 2 Kota Semarang mendapatkan nilai yang masih cukup rendah dibandingkan pada kompetensi teks lainnya. Dimana hasil belajar peserta didik saat ulangan harian hanya mencapai ketuntasan belajar masih dibawah 59,37\% dengan dengan nilai minimal (KKM) 70,00. Hal ini di bawah standar. Melihat hasil yang rendah pada materi tersebut, maka peneliti selaku guru di Madrasah Tsanawiyah Negeri 2 Kota Semarang, merasa tergugah untuk memperbaiki proses pembelajaran. Perbaikan proses pembelajaran ini diharapkan dapat memperbaiki pembelajaran dan pencapaian hasil yang diharapkan, salah satunya dengan cara Penelitian Tindakan Kelas (PTK). Hal ini sesuai dengan pendapat Wardani,dkk (2007:1-4) yang menyatakan bahwa PTK adalah penelitian yang dilakukan oleh guru di dalam kelasnya sendiri melalui refleksi diri, dengan tujuan untuk memperbaiki kinerjanya sebagai guru, sehingga hasil belajar siswa meningkat dan memenuhi standar Kriteria Ketuntasan Minimal (KKM).

Analisis ini didasarkan pada pengalaman bahwa pelajaran menulis materi yang bersifat interaktif, praktek langsung dan membutuhkan konsentrasi penuh yang membawa konsekuensi 


\section{LANGUAGE : Jurnal Inovasi Pendidikan Bahasa dan Sastra Vol 2. No 1. Februari 2022, e-ISSN : 2807-1670 | p-ISSN : 2807-2316}

terhadap proses belajar-mengajar yang didominasi oleh guru melalui metode ceramah, akibatnya siswa kurang terlibat dan cenderung pasif. Untuk itu diperlukan sebuah strategi belajar baru yang lebih memberdayakan keikutsertaan siswa dalam proses belajar secara aktif dan menyenangkan sehingga merangsang perkembangan proses intelektualnya. Salah satu strategi yang coba diterapkan oleh serang guru adalah dengan mencari model pembelajaran yang sesuai.

Model pembelajaran merupakan kerangka konseptual yang melukiskan prosedur yang sistematis dalam pengorganisasian pengalaman belajar untuk mencapai tujuan belajar. Jadi model pembelaran cenderung perskriptif, yang relatif sulit dibedakan dengan strategi pembelajaran. Model pembelajaran sangat diperlukan untuk memandu proses belajar secara efektif. Model pembelajaran yang efektif adalah model pembelajaran yang memiliki landasan teoritik yang humanistik, lentur, adaptif, berorientasi kekinian, memiliki sintak pembelajaran yang sederhana, mudah dilakukan, dapat mencapai tujuan, dan hasil belajar yang optimal ( Zainal Aqib dan Ali Murtadlo, 2016: 3). Dan salah satu model pembelajaran yang diperlukan untuk mencapai pembelajaran yang efektif dalam kurikulum 2013 adalah model Project based Learning.

Project based learning menurut Nursalim dan Efendi dalam Deni darmwan (2018:160) menyatakan bahwa dalam model pembelajaran project based learning peserta didik diminta untuk mengerjakan tugas yang biasa dikenal dengan proyek. Proyek tersebut telah dirancang secara sistematis. Selain itu, peserta didik juga diminta untuk menunjukkan kinerjanya dan bertanggung jawab terhadap hasil kerjanya. Dan model pembelajaran ini lebih cocok diterapkan pada materi yang parktek langsung bukan sekedar teoritis. Diharapkan dengan model project based learning ini dapat meningkatkan ketrampilan menulis fabel atau legenda baik secara lisan maupun tulisan. Untuk itulah, model project based learning ini diterapkan peneliti dalam pembelajaran teks fabel atau legenda pada peserta didik kelas VII F MTs Negeri 2 Kota Semarang semester genap tahun pelajaran 2019/2020 .

\section{METODE PENELITIAN}

Penelitian berjudul Penggunaan Model Project Based Learning untuk meningkatkan ketrampilan menulis teks fabel atau legenda ini dilakukan di MTs Negeri 2 Kota Semarang selama tiga bulan yakni pada bulan Februari sampai April 2020. Dengan mengambil subjek yaitu peserta didik kelas VIIF MTs. Negeri 2 Kota Semarang, dengan jumlah keseluruhan peserta didik di kelas VII F adalah 32 orang. Rinciannya terdiri dari 19 anak perempuan dan 13 anak laki-laki dengan karekteristik tingkat kemampuan rata-rata. Faktor yang hendak diteliti dalam penelitian ini yaitu tingkat pemahaman peserta didik dapat dilihat dari faktor : (a) keaktifan peserta didik dalam mengikuti proses belajar-mengajar, dan (b) peningkatan ketrampilan menulis teks fabel atau legenda.

\section{Teknik Analisis Data}

Tingkat pemahaman peserta didik dapat telihat dari hasil keaktifan dan hasil belajar peserta didik. Dari hasil keaktifan peserta didik dibedakan antara lain hasil baik (B), Cukup aktif (C), dan kurang $(\mathrm{K})$. adapun hasil belajar peserta didik ditentukan dengan tuntas jika nilai yang diperoleh minimal KKM yakni 70, dan hasil tidak tuntas jika nilai yang didapat kurang dari 70 .

\section{Teknik Pengumpulan Data}

Metode pengumpulan data dilakukan melalui tiga tahapan dengan uraian sebagai berikut :

1. Pra Siklus adalah pengumpulan data keaktifan peserta didik dan data nilai hasil belajar peserta didik sebelum dilakukan penelitian

2. Siklus I adalah pengumpulan data keaktifan peserta didik dan data nilai hasil belajar peserta didik pada pelatihan I

3. Siklus II adalah pengumpulan data keaktifan peserta didik dan data nilai hasil belajar peserta didik pada pelatihan II 


\section{Desain Penelitian}

Penelitian ini dilaksanakan dalam dua suklus yang masing-masing melalui empat tahap yaitu : tahap perencanaan, tahap pelaksanaan, tahap pengamatan/ pengumpulan instrumen data, dan tahap refleksi.Berikut ini gambaran tahapan pelaksanaan penelitian tindakan kelas :

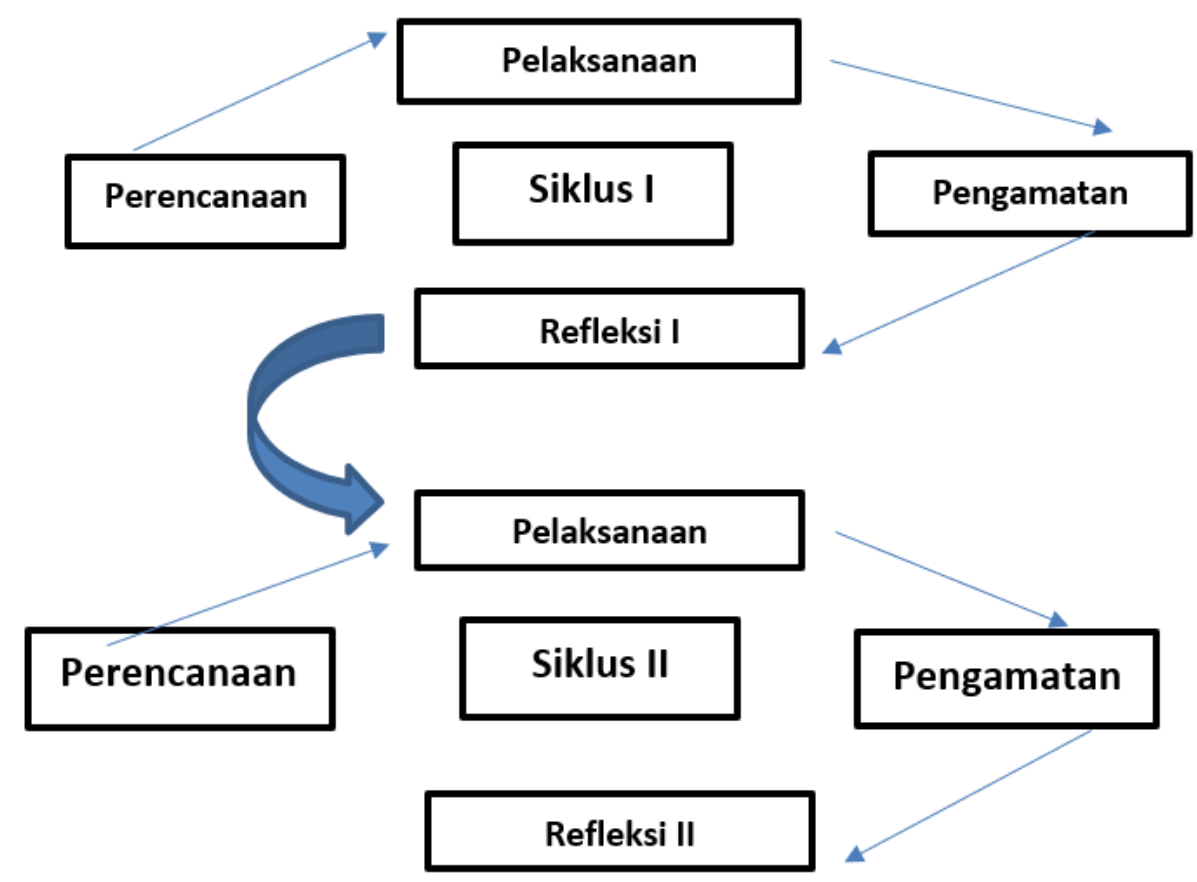

Gambar 1. Siklus Penelitian Tindakan Kelas

\section{HASIL DAN PEMBAHASAN}

\section{A. Deskripsi Kondisi Awal}

Penelitian Tindakan Kelas ini dilaksanakan di Kelas VIIF MTs Negeri 2 Kota Semarang. Jumlah keseluruhan peserta didik di kelas VIIF adalah 32 orang. Keaktifan mereka selama pembelajaran di kelas rata-rata masih rendah. Berdasarkan observasi diketahui bahwa peserta didik yang keaktifannya dengan katagori rendah ada $53,13 \%$, sedang ada $28,12 \%$, dan tinggi ada 18,75 \%. Hasil belajar mereka pada mata pelajaran Bahasa Indonesia, dilihat dari nilai ulangan setelah menyelesaikan 1 bulan pembelajaran (Teks Fabel) rata-rata nilai mereka masih rendah. Peserta didik yang memperoleh nilai dibawah KKM (Belum Tuntas) ada 40,63 $\%$, peserta didik yang memperoleh nilai $=/>$ KKM (tuntas) hanya ada 59,37 \% .

\section{B. Hasil Penelitian}

Hasil penelitian menunjukkan bahwa model project based learning pada setiap siklus mengalami mengalami dampak peningkatan ketrampilan menulis teks fable pada siswa. Hal ini dapat terlihat dari keaktifan dalam proses belajar yang dilakukan peserta didik di kelas dan hasil belajar siswa dalam menulis teks fabel. Perbandingan hasil belajar dan keaktifan peserta dalam pembelajaran menggunalan project based learning pada setiap siklus sebagai berikut :

Tabel 1. Daftar Nilai Peserta Didik dalam Pembelajaran Pra Siklus, Siklus 1 dan Siklus

\begin{tabular}{|c|l|c|c|c|}
\hline No & \multicolumn{1}{|c|}{ Nama Siswa } & Nilai Pra Siklus & Siklus 1 & Siklus 2 \\
\hline 1 & Ahmad Khoiru Sajidin & 70 & 80 & 80 \\
\hline 2 & Andini Salsabila & 60 & 55 & 60 \\
\hline 3 & Anita Chici Fitri & 80 & 85 & 90 \\
\hline 4 & Annasya Desmalia & 70 & 70 & 80 \\
\hline
\end{tabular}


LANGUAGE : Jurnal Inovasi Pendidikan Bahasa dan Sastra

Vol 2. No 1. Februari 2022, e-ISSN : 2807-1670 | p-ISSN : 2807-2316

\begin{tabular}{|c|l|c|c|c|}
\hline 5 & Aulya Parasmeta & 70 & 75 & 70 \\
& Harsono & & & \\
\hline 6 & Azzakiyah Putri & 60 & 60 & 70 \\
\hline 7 & Farel Rasya Al Aziz & 60 & 70 & 80 \\
\hline 8 & Fhayanalus Syafaah Nur & 70 & 75 & 80 \\
\hline 9 & Fima Cindy Larasati & 80 & 80 & 70 \\
\hline 10 & Iatiqomah Nur Rama & 80 & 70 & 80 \\
\hline 11 & Marsha Ammara Rushda & 70 & 95 & 90 \\
\hline 12 & Maulana Lukman Hakim & 60 & 70 & 80 \\
\hline 13 & Maulida Gita Lisnawati & 70 & 90 & 80 \\
\hline 14 & Muhammad Agabiel A. & 60 & 60 & 70 \\
\hline 15 & Muhammad Fauzan & 60 & 65 & 70 \\
\hline 16 & Naifah Atha Ablyyu & 70 & 80 & 80 \\
\hline 17 & Naldo Alim Muhammad & 60 & 60 & 70 \\
\hline 18 & Nisyza Ayu Ardila & 60 & 70 & 70 \\
\hline 19 & Novi Aulia Argianti & 80 & 85 & 80 \\
\hline 20 & Nur Azizah Lestari & 70 & 75 & 80 \\
\hline 21 & Putri Maysella Noor & 80 & 90 & 90 \\
\hline 22 & Putri Rania Safira & 60 & 65 & 70 \\
\hline 23 & Rachmandira Fairinnuha & 50 & 55 & 70 \\
\hline 24 & Rahman Nuzul & 70 & 70 & 80 \\
\hline 25 & Rashya Said Al Firman & 60 & 70 & 70 \\
\hline 26 & Rifani Alya Septiyassa & 70 & 80 & 80 \\
\hline 27 & Rifky Aditya Saputra & 70 & 65 & 80 \\
\hline 28 & S. Jarrel Paramahamsa & 70 & 75 & 70 \\
\hline 29 & Sharif Al Buchori & 50 & 55 & 60 \\
\hline 30 & Syafira Ainun Nissa R & 70 & 85 & 90 \\
\hline 31 & Saoqi Taufik & 80 & 75 & 80 \\
\hline 32 & Zakka Firdaus R & 60 & $\mathbf{2 3 1 5}$ & $\mathbf{2 4 3 0}$ \\
\hline & Jumlah Nilai & $\mathbf{2 1 5 0}$ & $\mathbf{7 2 , 3 4}$ & $\mathbf{7 5 , 9 4}$ \\
\hline & $\quad$ Nilai Rata-rata & $\mathbf{6 7 , 1 9}$ & $\mathbf{3 1 , 2 5} \%$ & $\mathbf{9 0 , 6 3 \%} \%$ \\
\hline & Belum Tuntas (< KKM) & $\mathbf{4 0 , 6 3 \%}$ & $\mathbf{5 9 , 3 7 \%}$ & \\
\hline & Tuntas (=/ > KKM) & & & \\
\hline & & & & \\
\hline
\end{tabular}

Dari hasil tes yang diberikan ke peserta didik, maka bila dibandingkan dengan hasil belajar pesera didik pada kondisi awal, hasil belajar pada siklus 1 dan hasil belajar pada siklus 2 ini mengalami peningkatan. Hal ini dapat dilihat pada tabel berikut ini :

Tabel 2. Hasil Belajar Kondisi Awal, Siklus 1 dan Siklus 2

\begin{tabular}{|c|l|c|c|c|}
\hline No & \multicolumn{1}{|c|}{ Kategori Nilai } & Pra Siklus & Siklus 1 & Siklus 2 \\
\hline 1 & Nilai rata-rata & 67,19 & 72,34 & 75,94 \\
\hline 2 & Belum Tuntas (<KKM) & $40,63 \%$ & $31,25 \%$ & $, 9,37 \%$ \\
\hline 3 & Tuntas (=/>KKM) & $59,37 \%$ & $68,75 \%$ & $90,63 \%$ \\
\hline
\end{tabular}




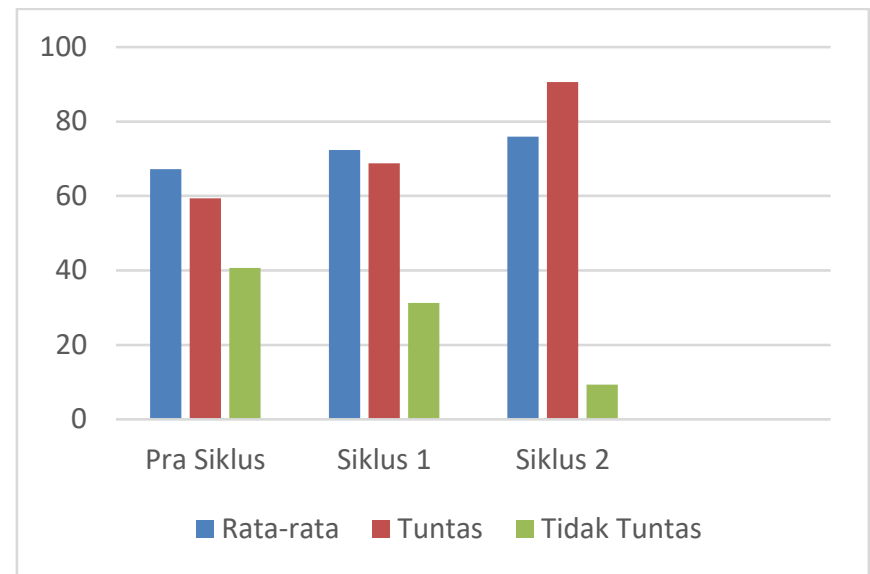

Gambar 2. Grafik Hasil Belajar Siswa

Tabel. 3 Keaktifan Peserta Didik Kondisi Awal, Siklus 1 dan 2

\begin{tabular}{|c|l|c|c|c|}
\hline No & Kategori Keaktifan & Kondisi Awal & Siklus 1 & Siklus 2 \\
\hline 1 & Tinggi & $18,75 \%$ & $25,00 \%$ & $31,25 \%$ \\
\hline 2 & Sedang & $28,12 \%$ & $37,50 \%$ & $56,25 \%$ \\
\hline 3 & Rendah & $53,13 \%$ & $37,50 \%$ & $12,50 \%$ \\
\hline
\end{tabular}

\section{Pembahasan}

Berdasarkan table 2 diketahu bahwa pada siklus 1 diperoleh rata-rata nilai yang diperolah peserta didik untuk mata pelajaran Bahasa Indonesia KD tentang Teks fabel (KKM 70 ) adalah 72,34 . Hal ini berarti terdapat kenaikan nilai rata-rata dimana kondisi awal yang diperoleh yatu 67,19. Kalau dipresentasikan berdasarkan katagori belum tuntas ( $<\mathrm{KKM})$ dan tuntas (=/ > KKM) adalah sebagai berikut : presentasi yang belum tuntas ada 31,25\% sedangkan presentasi sudah tuntas ada $68,75 \%$

Adapun untuk hasil nilai peserta didik di atas menunjukkan bahwa hasil belaja pada kondisi awal, hasil belajar pada siklus 1 ini mengalami peningkatan dalam hal ketuntasan belajar. Presentasi peserta didik yang belum tuntas mengalami penurunan dari kondisi awal ke siklus 1 yakni dari 40,63\% turun menjadi $31,25 \%$. Sedangkan presentasi peserta didik yang sudah tuntas pada siklus 1 mengalami peningkatan dari kondisi awal yakni dari 59,37\% naik menjadi $68,75 \%$.

Untuk siklus II diketahui bahwa rata-rata nilai yang diperolah peserta didik untuk mata pelajaran Bahasa Indonesia KD tentang Teks fabel (KKM 70) adalah 75,94. Hal ini berarti terdapat kenaikan nilai rata-rata dimana kondisi siklus 1 yang diperoleh yatu 72,34 . Berarti terdapat peningkatan nilai rata-rata sebesar 3,6 dari siklus 1 ke siklus 2. Kalau dipresentasikan berdasarkan katagori belum tuntas $(<\mathrm{KKM})$ dan tuntas $(=/>\mathrm{KKM})$ adalah sebagai berikut : pesentase yang belum tuntas ada 9,37\% dan resentasi sudah tuntas ada 90,63\%.

Jika dibandingkan antara ahsil belajar dari kondisi awal dengan hasil belajar pada kondisi siklus 1 dan hasil belajar pada siklus 2 ini mengalami peningkatan dalam hal ketuntasan belajar. Nilai rata-rata yang diperoleh kondisi awal ada kenaikan pada siklus pertama yakni dari rata-rata 67,19 naik menjadi 72,34 itu berarti ada peningkatan sebesar 5,15 angka. Sedangkan pada siklus kedua pun terdapat kenaikan rata-rata nilai dari siklus I ke siklus II yakni dari nilai rata-rata 72,34 menjadi 75,94, berarti terdapat kenaikan nilai rata-rata sebesar 3,60. Jadi dari kondisi awal hingga siklus kedua terdapat kenaikan nilai rata-rata sebesar 8,75..

Adapun hasil belajar peserta didik yang belum tuntas pada Siklus II, mengalami penurunan dari kondisi awal, kondisi siklus 1 ke siklus 2 yakni dari 40,63 pada kondisi awal turun menjadi 31,25\% pada siklus pertama dan turun kembali menjadi 9,37\%. Sedangkan presentasi peserta didik yang sudah tuntas pada siklus 2 mengalami peningkatan dari kondisi siklus 1 serta kondisi awal yakni dari 59,37\% naik menjadi $68,75 \%$ pada siklus pertama dan naik lagi menjadi 90,63\% pada siklus kedua. Berarti ada kenaikan presentase ketuntasan dari 


\section{LANGUAGE : Jurnal Inovasi Pendidikan Bahasa dan Sastra Vol 2. No 1. Februari 2022, e-ISSN : 2807-1670 | p-ISSN : 2807-2316}

kondisi awal ke siklus 1 sebesar 9,38\%, sedangkan kenaikan presentase ketuntasan dari siklus 1 ke siklus 2 sebesar 21,88\%. Jadi dari kondisi awal hingga siklus kedua terdapat kenaikan presentase ketuntasan hasil belajar sebesar 31,26\%.

Berdasarkan hasil pengamatan dan analisis di atas, maka dapat disimpulkan bahwa jika dilihat dari aktivitas belajar siswa maka hasil tersebut belum kelihatan baik karena belum semua siswa terlihat aktif dalam proses pembelajaran, hal ini mungkin karena siswa belum terbiasa dengan model pembelajaran seperti ini. Namun begitu melihat adanya kenaikan dalam perolehan nilai rata-rata kelas dan juga kenaikan ketuntasan belajar yang diperoleh, maka siklus pertama ini sudah cukup baik, meskipun belum sangat baik.

Adapun dilihat dari table 3 untuk keaktifan pada Siklus 1 didapatkan data bahwa, presentase peserta didik yang memiliki keaktifan rendah ada $37,50 \%$, sedang ada $37,50 \%$, dan tinggi ada $25 \%$. Hal ini terdapat peningkatkan keaktifan jika dibandingkan pada pra siklus dimana keaktifan siswa rendah ada 53,13\%, keaktifan sedang ada 28,12\%, dan keaktifan tinggi ada $18,75 \%$. Keaktifan peserta didik pada siklus 2 ini didapatkan data bahwa, presentase peserta didik yang memiliki keaktifan rendah ada $12,50 \%$, sedang ada $56,25 \%$, dan tinggi ada $31,25 \%$. Sehingga jika dilihat dari keaktifan siswa jika dihitung dari yang keaktifan tinggi dan sedang maka sudah mencapai $87,5 \%$, dengan katagori baik. Tetapi hal ini berarti keaktifan peserta didik sudah mencapai nilai yang baik karena secara keseluruhan pencapaian keaktifan peserta didik mencapai $87,5 \%$ melebihi $85 \%$, jadi bisa dikatakan bahwa PTK dengan model pembelajaran model project based learning ini sudah berhasil. maka pembelajaran secara umum telah berjalan dengan sangat baik.

Dengan penggunaan model project based learning ini menunjukkan adanya peningkatan hasil belajar peserta didik dan keaktifan peserta didik. Hal ini sejalan dengan hasil penelitian Denny Asprilla (2017) dalam tesisnya yang berjudul "Implementasi Model Pembelajaran Project Based Learning untuk Meningkatkan Aktivitas dan Hasil Belajar Siswa Kelas XI TKR 2 pada Mata Pelajaran Gambar Teksnik di SMK N 2 Pengasih". Hasil penelitiannya menunjukkan bahwa pelaksanaan pembelajaran menggunakan model pembelajaran project based learning dapat meningkatkan aktivitas dan hasil belajar siswa.

\section{KESIMPULAN}

Berdasarkan hasil penelitian dengan judul "Penggunaan Model Project Based Learning Untuk Meningkatkan Ketrampilan Menulis Teks Fabel Atau Legenda" , dapat disimpulkan bahwa model pembelajaran project based learning yang dilaksanakan di MTs Negeri 2 Kota Semarangpada peserta didik kelas VIIF mampu meningkatkan motivasi peserta didik dalam pelajaran Bahasa Indonesia khususnya materi menulis teks fabel atau legenda. Hal ini terlihat dari adanya peningkatan nilai keaktifan peserta didik dan hasil belajar peserta didik.

Pembelajaran dengan menggunakan model pembelajaran project based learning ini menunjukkan bahwa keaktifan dari kondisi awal ke siklus 1 dan ke siklus 2 persentase peserta didik yang keaktifannya dengan katagori rendah terus menerus mengalami penurunan, yakni $53,13 \%-37,50 \%-12,50 \%$. Sedangkan yang katagori sedang terus menerus mengalami peningkatan, yakni $28,12 \%-37,50 \%-56,25 \%$. Adapun yang katagri tinggi pun terus-menerus mengalami kenaikan, yakni $18,75 \%-25,00 \%-31,25 \%$.

Penelitian dengan model project based learning ini menunjukkan bahwa hasil belajar siswadari kondisi awal ke siklus 1, dan ke siklus 2 mengalami peningkatan setelah dilakukan tindakan. Persentase peserta didik yang belum tuntas secara terus-menurus mengalami penurunan, yakni $46,63 \%-31,25 \%-9,37 \%$. Adapun untuk peserta didik yang mengalami ketuntasan hasil belajar terus menerus memgalami peningkatan yakni, 59,37\% -68,75\% $90,63 \%$. Nilai rata-rata pun dari kondisi awal ke siklus 1 dan ke siklus 2 pun terus-menerus mengalami peningkatan, yakni 67,19 -72,34 -78,94. Indikator keberhasilan PTK ini adalah, bahwa PTK ini dikatakan berhasil jika presentase peserta didik yang nilai hasil belajarnya sudah tuntas mencapai menimal 85\%. Dan dari table menunjukkan bahwa persentase peserta didik yang nilainya tuntas sudah mencapai $90,63 \%$, maka PTK ini sudah berhasil. 


\section{DAFTAR PUSTAKA}

Abidin, Y. 2012. Pembelajaran Membaca Berbasis Pendidikan karaakter. Bandung : Refika Aditama

Arikunto, Suharsini. 2006. Prosedur Penelitian : Suatau Pendekatan Praktek. Jakarta : Rineka Aqib, Zainal. 2017. Model-model, Media, dan Strategi Pembelajaran Konstekstual. Bandung: Yrama Widya.

Aqib, Zainal dan Ali Murtadlo. 2016. Kumpulan Metode Pembelajaran Kreatif dan Inovatif. Bandung : Satunusa.

Darmawan, Deni.2018. Model Pembelajaran Di Sekolah. Bandumg : PT Remaja Rosdakarya. Depdiknas, 2005. Prinsip dan Pendekatan dalam Pembelajaran Bahasa Indonesia, Bahan Pelatihan Terintegrasi Berbasis Kompetensi Guru SMP. Jakarta :Depdiknas

Depdiknas.2005. Kurikulum Bahasaa Indonesia dan Sastra Indonesia. Bahan Pelatihan Terintegrasi Berbasis Kompetensi Guru SMP. Jakarta :Depdiknas

Depdiknas.2005. Landasan Bahasaa Indonesia dan Sastra Indonesia. Bahan Pelatihan Terintegrasi Berbasis Kompetensi Guru SMP. Jakarta :Depdiknas

Harjanto. 2008. Perencanaan Pengajaran. Jakarta :Rineka Cipto

PLPG. 2009. Modul PLPG Menulis. Jakarta: UNJ

Sanjaya, Wina. 2008. Strategi Pembelajaran Berorientasi Standar Proses Pendidikan. Jakarta : Kencana Prenada Media Group.

Slamet, St.Y. 2007. Dasar-dasar Ketrampilan Berbahasa Indonesia. Surakarta: Press. Solchan, 1996. Interaksi Belajar Mengajar Bahasa Indonesia. Malang : IKIP Malang Sukidin, dkk. 2002. Manajemen Penelitian Tindakan Kelas. Jakarta : Insan Cendikia. Suparno dan M.Yunus.2008.Ketrampilan Dasar Menulis. Jakarta :Universitas Terbuka. Susilawati, Angraeni. 2005. Media Pembelajaran. Jakarta : Rineka

Sutirjo dan Sri Istuti Mamik. 2005. Pembelajaran Efektif dalam Kurikulum 2006. Malang : Bayumedia Publishing.

Tarigan, H.G.2008. Menulis Sebagai Suatu Ketrampilan Berbahasa. Bandung: Angkasa. Triani, Nani. 2012. Panduan Melaksanakan PTK. Jakarta : Luxima Metro Media Undang-undang Republik Indonesa No 20 Tahun 2003 tentang Sistem Pendidikan Nasional. Wardani, I.G.A.K, dkk. 2007. Penelitian Tindakan Kelas. Jakarta : Universitas Terbuka. Wardani, I.G.A.K,dkk.2009. Teknik Menulis Karya Ilmiah : Jakarta: Universitas Terbuka 